Irena GROCHOWSKA

IEiB UKSW Warszawa

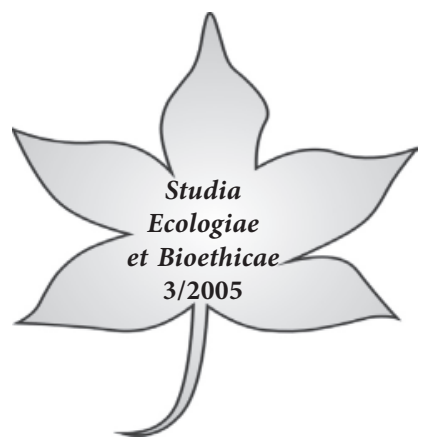

\title{
Tożsamość i kondycja człowieka
}

\section{Wstęp}

Człowiek nie jest wytworem, którego można określić przez wskazanie jego cech i którego można wyczerpująco opisać niczego nie pomijając. Opis cech człowieka nie wyczerpuje wiedzy o nim. Człowiek różni się od innych gatunków nie tylko pod względem biologicznym, ale przede wszystkim ze względu na szczególne spojrzenie, którym patrzy na świat, aby zadawać pytania.

Chantal Delsol - francuska profesor filozofii politycznej w swojej książce Człowiek późnej nowoczesności charakteryzuje późną nowoczesność jako epokę paradoksów, która „odżegnuje się od ideologii totalitarnych, ale kontynuuje ich dzieło depersonalizacji, odrzuca dziedzictwo tradycji chrześcijańskiej, ale pozostaje wierna idei godności pojedynczego człowieka". Godność człowieka zakłada istnienie osoby i wyjątkowość człowieczeństwa i jest postulatem wiary. Idea godności osobistej opiera się na całym odziedziczonym świecie kultury. Nauka jak dotąd nie ustaliła definicji godności ludzkiej, w zamian natomiast przywołuje prawa człowieka jako antidotum na wszelkie problemy współczesnego współistnienia.

Zdaniem Hryniewicza ${ }^{1}$ większość ludzi ucieka przed pytaniami o samego siebie w obawie przed sobą i przed nieprzeniknioną tajemnicą własnego istnienia. Ludzie wolą żyć z dala od samych siebie, pochłonięci konkretnymi zajęciami i zadaniami, które niesie codzienność. Zadawalają się tym co czynią, nie pytając o głębszy sens człowieczeństwa. Tajemnica człowieczeństwa zostaje tajemnicą, także dla tych, którzy jej zawierzyli, bowiem, wiara nie usuwa tajemnicy.

\section{Tożsamość i jej wymiary}

Tożsamość dla człowieka oznacza poczucie jedności i ciągłości wewnętrznej, trwałej w czasie i w różnych okolicznościach, połączonej ze zdolnością zachowania łączności z realnym systemem wartości². Cencini i Manenti wskazują na

W. Hryniewicz, Pascha Chrystusa w dziejach człowieka i wszechświata, s. 41.

A. Cencini, A. Manenti, Psychologia a formacja, Kraków, 2002, 128. 
przeciwieństwa tożsamości, które charakteryzują się brakiem poczucia wartości. Konsekwencją braku tożsamości jest nieśmiałość, nieufność, niepewność oraz brak stałości, którą cechuje zdecydowanie. Człowiek, kiedy nie utożsamia się z konkretnymi wartościami i nie interioryzuje ${ }^{3}$ ich $\mathrm{w}$ swoim życiu popada w poczucie pustki egzystencjalnej. Tożsamość można rozpatrywać na wielu płaszczyznach.

Dla potrzeb moich rozważań chciałabym zwrócić uwagę na wybrane przeze mnie trzy typy tożsamości:

- tożsamość biologiczną

- tożsamość psychologiczną

- tożsamość duchową

\subsection{Biologiczny aspekt tożsamości według koncepcji Francisco Varela}

Francisco Varela ${ }^{4}$ poszukuje odpowiedzi na pytanie, „czym jest tożsamość biologiczna, czy rzeczywiście mamy do czynienia z jedną tożsamością, umożliwiającą nam poznanie i rozumienie, a zarazem zmuszającą komórki naszego organizmu do organizowania się w spójną całość, układ immunologiczny do wyznaczania granic ciała, a mózg do generowania procesów tworzących umysł, świadomą tożsamość każdego człowieka"?

W przypadku analizowania tożsamości biologicznej powinniśmy zwrócić uwagę na dwa poziomy organizacji tożsamości tj; poziom oddziaływań miejscowych i poziom globalny. Na najniższym poziomie oddziaływań mamy do czynienia ze związkami chemicznymi, materią nieożywiona i ożywioną. Interesuje nas moment przejścia poszczególnych cząsteczek w strukturę stanowiącą zalążek tożsamości organizmu.

Varela podkreśla, że dzięki oddziaływaniom np. związanym z przekazywaniem bodźców między zmysłami a układem motorycznym powstaje dynamiczny układ powiązań, który stanowi o zakresie możliwości świadomego postrzegania. Zjawisko to natomiast stanowi jakiś konkret, który z kolei tworzy tożsamość na danym poziomie organizacji.

Możnaby uznać, że organizmy stanowią splot wielu takich „nie umiejscowionych tożsamości". Każdy organizm składa się z wielu pomniejszych tożsamości, które są innym obliczem tej samej osoby np. komórkowej, immunologicznej, umysłowej i wielu innych.

Ważna jest refleksja nad przejściem od pojedynczych zjawisk miejscowych do zaistnienia tożsamości żywego organizmu. Jak wyjaśnić unikalne procesy prowadzące od powstania pojedynczych komórek, jako jednostek strukturalnych do powstania żywej istoty. Varela nazwał taki proces logicznym pierwotnym sprzę-

Rulla definiuje interioryzację, jako proces przyjmowania przez człowieka wartości objektywnych jako swoich własnych, wewnętrznych norm postępowania.

4 F. VArela, Gdy pojawia się JA, w; Trzecia Kultura /red/ J. Brockman, Warszawa, 1996, 288-298. 
żeniem zwrotnym, opisał on układ wytwarzający elementy budujące granicę, odcinające go od reszty świata. Tak właśnie zachowuje się komórka - po prostu jest, sama wyznaczyła sobie granicę w postaci błony komórkowej, odróżniając się od reszty świata, zachowując własną odrębność.

Następna refleksja dotyczy działania układu nerwowego, nie możemy rozpatrywać mózgu jako maszyny przetwarzającej dane, bo dane do każdej maszyny, czy komputera muszą być wprowadzane, co oznaczałoby, że taki układ ma określone wyjścia i wejścia. Okazuje się, ze mózg jest pod względem operacyjnym, obiegiem zamkniętym. Dynamika wewnętrznych procesów zachodzących w mózgu pozwala na powstanie znaczenia z oddziaływań, które nie miałyby żadnego znaczenia bez jego działania. Podobne spostrzeżenia dotyczą układu immunologicznego, który tworzy zamkniętą całość, posiada własną sieć wewnętrznych powiązań. Jest więc też strukturą określającą własne granice, a więc posiadającą tożsamość, która jest równoznaczna z tożsamością organizmu., której znaczenie nie ma związku z obroną przed jakąkolwiek agresją. Takie spojrzenie na układ immunologiczny jako afirmację tożsamości organizmu, a nie jako negację otaczającego go świata jest nowatorskie.

Człowiek z biologicznego punktu widzenia jest sobą, dzięki interakcjom, ale JA danej osoby nie istnieje w sposób namacalny, nie można go w żaden sposób umiejscowić, ale dzięki możliwości kontaktu z tym co na zewnątrz człowiek jest sobą.

Nowa jakość, która powstaje na fundamencie sieci zależności to stan spójności, który daje możliwość relacji z innymi spójnymi układami na danym poziomie. Sensy tożsamości poszczególnych układów mają różne zadania na różnych poziomach.

\subsection{Psychologiczny aspekt tożsamości}

Ważne w tożsamości jest JA, które jest punktem centralnym dla wszystkich procesów i funkcji osobowości, a więc integruje osobowość. Rulla ${ }^{5}$ proponuje wyróżnienie w JA dwóch aspektów: JA aktualne i JA idealne. JA aktualne przedstawia to, czym osoba jest w rzeczywistości-czy o tym wie, czy nie- wraz z jej potrzebami i zwyczajowym sposobem postępowania. JA idealne przedstawia to, kim osoba pragnie stać się. Jest to świat aspiracji, pragnień, planów, a niekiedy marzeń i złudzeń.

Te dwa aspekty tożsamości niekiedy są sprzeczne ze sobą, a w budowaniu własnej tożsamości to, kim jestem i to kim pragnę być powinny być zbieżne. Każdy rozdźwięk i niepewność stanowi obszar działania dla niepożądanych wpływów. Dla wyjaśnienia chcę dodać, że całkowita zbieżność nie jest wymogiem tożsamości, gdyż idealny układ równowagi byłby absurdalny i nie możliwy do osiągnięcia, ale chodzi o zapoczątkowanie tego procesu, jego stopniowe przybliżanie. Osoba sfrustrowana doświadcza niemożliwości w przezwyciężeniu roz-

5 A. Cencini, A. Manenti, Psychologia a formacja, Kraków, 2002, 125. 
dźwięku pomiędzy tym, kim jest a tym kim chciałaby być, dlatego żyje w mniej lub bardziej uświadomionym niepokoju.

\subsection{Duchowy aspekt tożsamości czyli tożsamość osobista}

Tożsamość poznana na poziomie duchowym nie jest jedną z wielu możliwych sensów, lecz jedynym sensem nadanym przez Boga życiu konkretnej osoby i leży na płaszczyźnie istnienia. Alphonso ${ }^{6}$ podaje, że cechą charakterystyczną sensu rozumianego jako „znaczenie” jest trwałość i przetrwanie. Człowieka nigdy nie męczy sens, dlatego w swoim ziemskim pielgrzymowaniu pozostawia to wszystko co nie ma sensu, a chwyta się tego, co go posiada. Tożsamość osobista (powołanie osobiste lub tożsamość integrująca) jest jakby żywą anteną, która nieustannie wychwytuje $\mathrm{z}$ atmosfery i z całego doświadczenia osobistego to, co ma sens. To co doświadczeniach innych poziomów życia (biologicznego, społecznego, psychologicznego) nie współbrzmi z sensem życia jest przez człowieka pozostawiane. Sens ma dwa aspekty; zewnętrzny (transcendentny) i wewnętrzny sens własnego życia.

Najprostszy wniosek jaki się nasuwa to ten, że człowiek nie jest dla Boga jednym $\mathrm{z}$ wielu w tłumie, nie jest dla Niego numerem pewnej serii, kartką z katalogu, lecz kimś niepowtarzalnie jedynym, ponieważ Bóg „zwraca się do niego po imieniu”. Rzeczywistość tę można by nazwać „tożsamością osobistą”, „osobistym ukierunkowaniem życia”, „powołaniem osobistym” albo najgłębszym i najprawdziwszym „JA".

\section{Odpowiedź na kulturę i cywilizację}

Każda kultura odpowiada na słabość i niesamowystarczalność człowieka, proponując pewne rozwiązania, nadając sens niepokojowi. Ale przecież żadna kultura nie może mieć odpowiedzi na wszystkie pytania, nie może rościć sobie pretensji do uniwersalności i czystej prawdy ${ }^{7}$.

Fundamentalne pytanie człowieka brzmi, co mam uczynić ze swoim życiem, abym był szczęśliwy. Potencjalność człowieka upoważnia ciągle do szukania nowych rozwiązań. Głównym problemem człowieka jest nie pogodzenie się z jego słabością i ułomnością. Człowiek nie chce zintegrować do swojego życia swoich słabości psychicznych i fizycznych.

O ile choroby, ułomności ciała są widoczne, to niespójności psychiczne i duchowe, które mają zasadniczy wpływ, są niewidoczne, ukryte i trudne do zinterpretowania. Niedojrzałość człowieka, rozprawianie się z prawdą o słabo-

H. Alphonso, Powołanie osobiste, zeszyty ignacjańskie nr 5, Gdynia, 1993, 16.

7 Ch. Delsol, Człowiek późnej nowoczesności, Kraków, 2003, 69. 
ści i skończoności człowieka prowadzi do nowych poszukiwań, a uwaga na tu i teraz jest rozproszona. Ciągle szukamy, uciekając przed problemami, które należą do nas.

Delsol podsumowując wiek XX twierdzi, że nasze utopijne oczekiwania nie zostały spełnione, więc odrzucamy nadzieje i każdą nową idee jako potencjalny zawód, ponieważ nie udało się stworzyć idealnego społeczeństwa, to najlepiej na nic nie liczyć, bo można się zawieść. Według Delsol dzisiejsza nadzieja polega na obywaniu się bez nadziei ${ }^{8}$. Świat kultury staje się domostwem, w którym może się schronić niepokój człowieka.

Jan Paweł II podkreślał, że jeżeli wiara nie stanie się kulturą będzie martwa. Wspólny świat kulturowy jest przyjęciem na siebie swojej ludzkiej kondycji.

\section{Człowiek późnej nowoczesności w ujęciu Ch. Delsol}

Człowiek świadomy swojej egzystencji i jej skończoności potrzebuje poczucia bezpieczeństwa, to poczucie zapewnia mu wspólnota polityczna oraz różnego rodzaju normy i prawa. Coraz częściej jesteśmy świadomi jako ludzie, że nie mamy powrotu do surowej natury i stąd jak Delsol nazywa uciekamy „do przodu”.

W tej ucieczce za wszelką cenę chcemy zanegować naszą skończoność i dążyć do samowystarczalności człowieka. Takiego człowieka Delsol nazywa człowiekiem późnej nowoczesności lub samowystarczalnym i w swojej rozważaniach charakteryzuje go. Taki człowiek „porzuca swój świat kulturowy, ponieważ sądzi, że jest niezależny, że nic nikomu nie jest winien, że nie dotyczą go odziedziczone długi. Pełna pychy wiara w samowystarczalność nie pozwala mu stworzyć żadnego wspólnego świata, bo taki świat można zorganizować tylko wokół uświadomionej skończoności własnego bytu, a świadomość i wyznanie własnej skończoności jako tragicznej rany wprowadzają człowieka $\mathrm{w}$ stan nierównowagi ${ }^{9}$. Współczesna jednostka nie jest w stanie zaspokoić swoich potrzeb, a potrzeby, które pojawiają wciąż się nowe są zaspakajane przez społeczeństwo polityczne poprzez różnego typu usługi.

\section{Cechy człowieka niesamowystarczaelnego według Ch. Delsol}

Człowiek niesamowystarczalny, uznający słabość swojego człowieczeństwa potrafi integrować się z innymi, nawiązywać dialog osobowy i jest świadomy swojej pozycji w świecie przyrody.

Człowiek jest jedynym, który zdaje sobie sprawę z kruchości swego bytu i z tego, iż jest tylko przechodniem i że nie jest całkiem przystosowany do życia w tym świecie. Świadomość własnej skończoności i niesamowystarczalności

Ch. Delsol, Esej o człowieku późnej nowoczesności, Kraków, 2003, 7.

9 Ch. Delsol, Esej o człowieku późnej nowoczesności, Kraków, 2003, 67-68.

10 Ch. Delsol, Esej o człowieku późnej nowoczesności, Kraków 2003, 67-68. 
wprowadzają człowieka w stan nierównowagi. Człowieka definiuje jego nieprzystosowanie - „chce tego czego nie ma i nie posiada tego, czego chce, chce nieśmiertelności i zawsze umiera, chce dobra, a czyni zło" ${ }^{10}$.

Człowiek, który godzi się na swoją słabość, szuka oparcia w Bogu, wie, że słabość staje się jego mocą. Wtedy dopiero jest w stanie budować osobową tożsamość, która wymaga skończoności. Uświadomienie własnej niewystarczlności pozwala mu utożsamiać się z kulturą i w ten sposób wyrażać swoje człowieczeństwo.

\section{Podsumowanie}

Człowiek dąży do wewnętrznej zgodności i spójności wszystkich poziomów tożsamości człowieka i wszystkich wymiarów ludzkiej egzystencji. Według Rulli spójność taka jest łaską, darem Boga, a także trudnym zadaniem dla każdego, możliwym wtedy, kiedy człowiek otwiera się na autotranscendencję (przekraczanie siebie).

Jedność rodzaju ludzkiego opiera się na wspólnej kondycji ${ }^{11}$. Sam termin kondycja oznacza, że człowiek nie jest neutralny. Kondycja wskazuje na ograniczenia i obciążenia człowieka, chociaż coraz częściej współczesny człowiek próbuje zaprzeczyć jej, sam określając kim chce być i próbując zajmować miejsce Boga. Współczesny indywidualizm jest samotnym podążaniem za tradycją społecznych utopii.

Delsol twierdzi, że najpewniejszą rzeczą jaką możemy powiedzieć o człowie$\mathrm{ku}$, jest samo istnienie jego kondycji, której uznanie jest możliwe pod warunkiem porzucenia teorii panowania. Nie jesteśmy niezależni od własnej kondycji, nie możemy się z niej wyzwolić, tak jak nie możemy wykreślić swojego wyglądu, kondycja jest jak nieuleczalna choroba.

Godność osoby wyrasta właśnie z rany skończoności. Wielkość człowieka polega na przyjmowaniu i rozwiązywaniu problemów, na bezustannej walce, a nie na posiadaniu panaceum na wszystkie ludzkie dolegliwości. Człowiek, który odrzuca rzeczywistość, pragnąc tworzyć samego siebie traci formę i upada. „Uświadomienie sobie ludzkiej kondycji oznaczałoby więc porzucenie możliwości na rzecz bytu, potencji na rzecz aktu" ${ }^{\prime 2}$. Człowiek, który nie uznaje ludzkiej kondycji staje się nieokreślony, nie zna swojej tożsamości, ogranicza się więc do materii, do biologicznego ciała, dba i upiększa je, szukając w tym spełnienia. Ale tożsamość wymaga określenia siebie, nie można być sobą, jeżeli nie wiadomo, kim się ma być.

11 Tamże, 25.

12 Tamże, 73. 


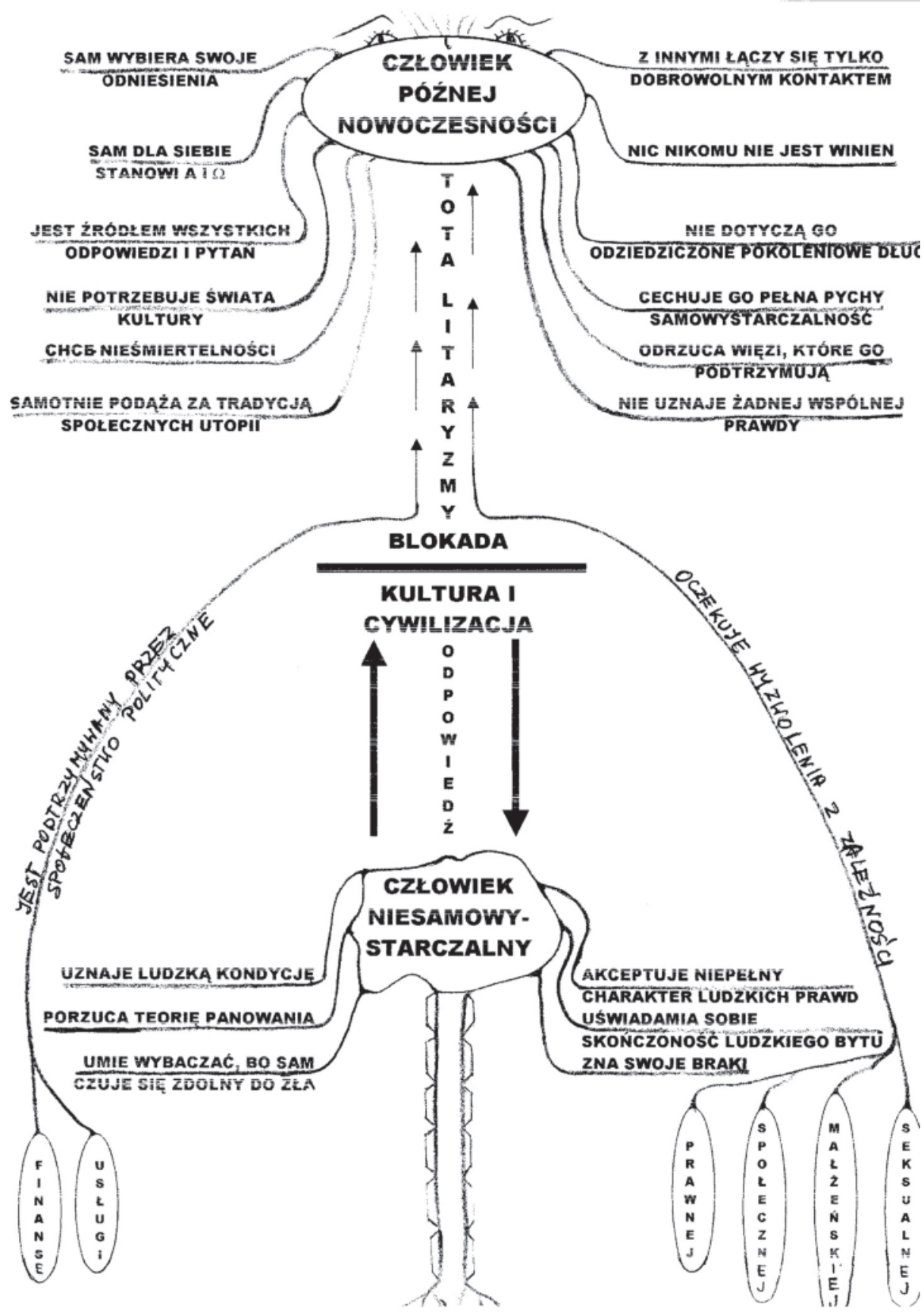

Autorska mapa myślowa opracowana na podstawie koncepcji człowieka późnej nowoczesności Ch. Delsol. 
Irena Grochowska

\section{Human's identity and condition}

\section{SUMMARY}

Human aims for internal integrity and unison at all levels of human are identity and all dimensions of human existence. According to Rull integrity is a gift from God, but also a task for everybody, only possible when a human being is open for autotranscendency. Unity of mankind is based on condition. The key word condition means that a human being is not neutral. The conditions indicates limitations and burdens of human being, although more and more frequently modern man tries to deny it, defining by himself who he wants to be and taking the place of God. Modern individualism is a lonely following of traditional utopia of society.

Delsol claims that the most certain thing, which we can say about a man, is the existence of his condition, which acceptance is possible under condition of leaving the theory of ruling. We are not independent from our condition, we can free ourselves from it like we cannot deny the way we look, the condition is like terminal illness.

A person's dignity grows from the wound of finiteness. Greatness of man is about receiving and solving problems, a constant struggle, not owing a panacea for all human problems. A man who rejects reality, wanting to create his own self loses form and falls. To realise about the human condition would mean leaving the possibility of existence, potentiality for act. Human being who does not accept the human condition becomes undefined, he does not know his identity, he is restricted to mass, to biological body, he looks after it, improves it looking for fulfilment. But identity requires defining, one cannot be oneself if one does not know what one should be.

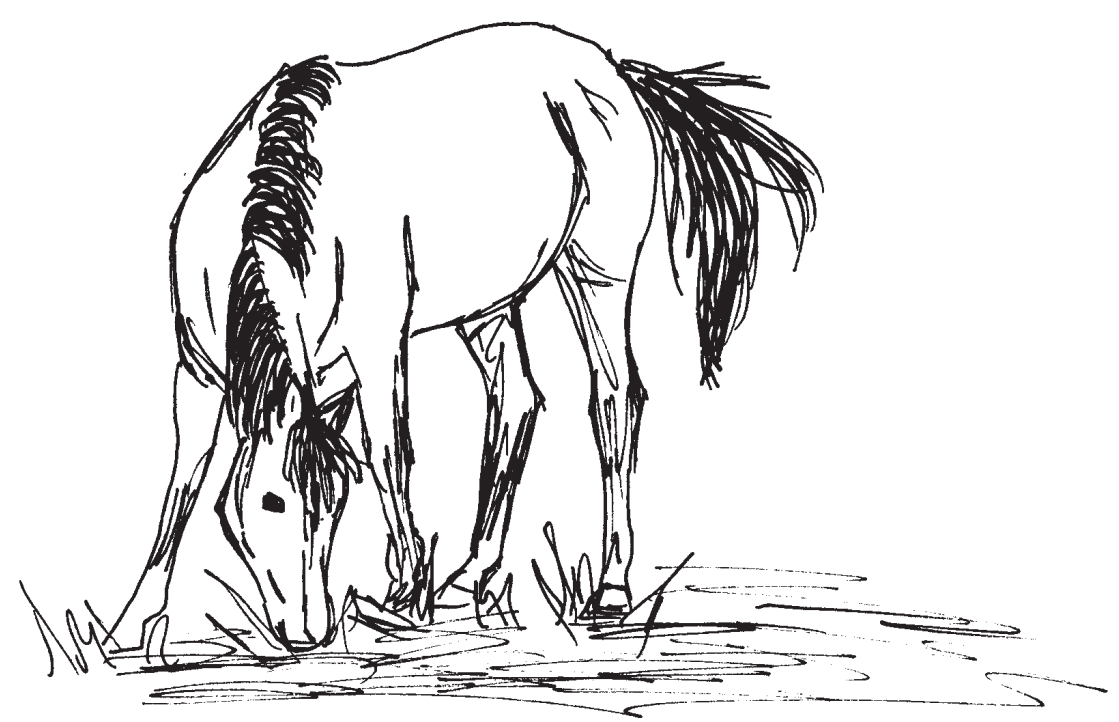

Rys. Marta Traczewska 